\title{
Towards a holistic view of moisture transport in historic buildings.
}

\author{
R.J. Pender ${ }^{a^{*}}$, E.A. Laycock ${ }^{\mathrm{b}}$, S. Hetherington ${ }^{\mathrm{b}}$ \\ ${ }^{a}$ Historic England, London, UK \\ ${ }^{b}$ Sheffield Hammam University, Sheffield, UK
}

\begin{abstract}
Water interacts with buildings at a range of overlapping scales, from envelope to pore. For 30 years building conservators have made practical field and laboratory investigations at the scale of elements such as walls. These have increased both our practical understanding, and our ability to deal with failure. This paper presents the argument that they also fundamentally outline a far more complete picture of the way that moisture travels into and through building systems under normal conditions.

This paper draws widely on research by the authors and others, to propose a consistent and simple picture of the interaction of water with 'traditional' buildings based on permeable materials. While some of the accepted wisdom is confirmed, other theories are challenged; particularly those around the nature of water transfer.

Peer-review under the responsibility of the organizing committee of the ICMB21.
\end{abstract}

Keywords: permeability; vapour transfer; liquid transfer; traditional buildings

\section{Introduction/Background}

Many of the problems in buildings, from fabric deterioration to problems of usability, can be traced to water in the building fabric, particularly in building walls. Changing moisture contents are associated with salt damage and dimensional instability; for example, elevated moisture contents with freeze-thaw damage, timber decay, and problems such as moulds. It is of great concern that these familiar issues are all exacerbated when buildings are retrofitted to reduce energy use and carbon emissions [1,2]. Moisture problems may arise from many sources and combinations of sources: from environmental events such as rain, snow, and flooding; from high ambient humidities and absorption by hygroscopic salts; from capillarity and escape of water from plumbing systems [1, 3]. Climate change and alterations in the nature of use of land in the catchment including urban expansion are understood to be multipliers; for example, buildings constructed where historically there was little flooding may now be at risk [4]. It has been generally assumed that increases in extreme weather conditions will heighten the hygrothermal cyclic loading of traditional building fabric made of porous materials, eventually increasing the rate of decay [5]; but it has also been shown that this type of construction is much more resistant to rain uptake than is commonly thought [6]. Current research by the authors is now suggesting that it equally provides excellent resistance to flood water. When moisture problems do occur, it is clear that successful recovery demands a good understanding of the fundamentals of water behaviour [7].With climate change pointing towards increasing episodes of extreme weather, the resilience of traditional construction needs to be correctly understood and properly reflected in building codes, so that these demonstrably robust buildings are retrofitted in ways which support or increase - rather than decrease - their resilience [8].

Water penetration and migration

Water interacts with buildings at all scales, from building envelopes to building elements to pores. Over the past 30 years building conservators have made numerous practical investigations at the 'element' scale, using research in the field and in the laboratory to examine the behaviour of complex assemblies such as walls when they are exposed to water [9]. Water enters these assemblies in different ways, via different mechanisms. Once there, it can be found in vapour or liquid phase, or (under the right conditions) as a solid, ice. All phases may occur simultaneously; and indeed at pore level it may not be possible to meaningfully distinguish between states. Phase exchanges are continuous, in response to local conditions within the pores as well as the action of the ambient conditions on (for example) surface evaporation and wall temperature [10]. For water to move from the ambient environment into, say, a wall, there must be water available at the surface, a route for that water to travel into the material, and a force to initiate that movement [11]. Gravity is one such force, but under the influence of

${ }^{*}$ Corresponding author. +44 20 79733133. robyn.pender@historicengland.org.uk

(C) The Author(s). This is an open access article distributed under the terms of the Creative Commons Attribution License (CC BY) $4.0 \mathrm{https}: / /$ creativecommons.org/licenses/by/4.0/, which permits unrestricted use, distribution and reproduction in any medium, provided the original author and source are credited. DOI: 10.14293/ICMB210048 
gravity alone, the water will only penetrate and continue to move within the material where there is a defect with a downward gradient which offers a path of low resistance to flow.

Other forces governing behaviour include capillary pressure, but this must be understood in a context that is markedly different to the 'bundled straw' model which explains water transfer in plants such as trees. As well as the interconnected pores within materials, active capillaries in building assemblies include fine cracks within the materials, and interfaces between components (for example where mortars meet masonry elements) [12]. Water can also move between dissimilar materials if they are in hydraulic contact with each other [13]. Thus, traditional construction provides a range of pathways for moisture uptake and migration.

Field and laboratory investigations into the interaction of traditional walls with driving rain and floodwater have demonstrated their high resistance to water transfer in comparison to cavity walls $[6,14]$. The internal and external finishes exert considerable influence on wetting and drying of solid walls, and even walls with high levels of moisture due to prolonged poor maintenance can be recuperated by the application of lime-based renders [15]. Current laboratory work is seeking to evaluate the rates of moisture uptake during flooding, and the effect of different mortar-brick combinations on wetting and drying. Exposed to a head of water, solid masonry walls demonstrate water uptake that, while significant in quantity, is very slow.

Discussion \& Conclusion

Field and laboratory studies of traditional walls have increased our practical understanding of how these perform and increased our ability to identify and deal with failure. More importantly, however, they have provided us with the information to construct a better picture of the way that water travels into and through permeable building envelopes under normal conditions, particularly for 'traditional' construction. This picture confirms some accepted ideas, but it challenges others, particularly those concerning infiltration under flooding, and the movement of water in vapour form through permeable materials. Further discussion and more research is required to fully understand the influence of critical factors; for example, in determining tipping points for driving rain absorption. As yet it is unclear if this depends mostly on the materials, on the structure of the building element (for example the presence of voids, or the types of interfaces), or the initial source of water (for example, if a building flaw has let water into the wall core). These more complete theorems of water in permeable building materials are urgently needed not only for improving our understanding of moisture problems, but also for better analysis of the risks inherent in current approaches to treatment and repair, and in particular energy retrofitting.

\section{References}

[1] D'Ayala, D. \& Aktas, Y.A. (2016). Moisture dynamics in the masonry fabric of historic buildings subjected to wind-driven rain and flooding. Building and Environment, 104 (2016), 208-220. https://doi.org/10.1016/j.buildenv.2016.05.015

[2] Giaccone, D., Santamaria, U. \& Corradi, M. (2020). An Experimental Study on the Effect of Water on Historic Brickwork Masonry. Heritage 2020, 3, 29-46. doi:10.3390/heritage3010003

[3] Pia, G. Casnedi, L. \& Sanna, U. (2016). Pore Size Distribution Influence on Suction Properties of Calcareous Stones in Cultural Heritage: Experimental Data and Model Predictions. Advances in Materials Science and Engineering Volume 2016, Article ID 7853156. http://dx.doi.org/10.1155/2016/7853156

[4] Cassar, M. and Pender, R. (2005). The impact of climate change on cultural heritage: evidence and response', ICOM-CC 14th Triennial meeting, The Hague, ed I. Verger, London: James and James, 610-616

[5] O’Shea, T.E. \& Lewin, J. (2020). Urban flooding in Britain: an approach to comparing ancient and contemporary flood exposure. Natural Hazards, 104:581-591. https://doi.org/10.1007/s11069-020-04181-8

[6] Laycock, E. \& Wood, C. (2014). Understanding and controlling the ingress of driven rain through exposed, solid wall masonry structures. Geological Society special publication, 391, 175-191.

[7] Wood, C. (2010). Understanding and controlling the movement of moisture through solid stone masonry caused by driving rain. Unpublished MSc by Research. March 2010. The University of Oxford/School of Geography and the Environment.

[8] Lamond, J., Rose, C., \& Joseph, R. (2016). Supporting the uptake of low cost resilience: summary of technical findings (FD2682). Defra, UK.

[9] English Heritage 2014. Practical Building Conservation: Building Environment. Routledge, London. 1 st edition 0754645584.

[10] Hall, C. \& Hoff, W.D. (2002). Water Transport in Brick, Stone and Concrete. CRC Press; 1st edition (5 Sept. 2002) 041922890X.

[11] Killip, I.R. \& Cheetham, D.W. (1984). The Prevention of Rain Penetration through External Walls and Joints by Means of Pressure Equalisation. Building and Environment, 19[2], 81-91.

[12] Pender, R (2001). The behaviour of moisture in the porous support materials of wall paintings: an investigation of some environmental parameters. Unpublished PhD, University of London/Courtauld Institute of Art.

[13] Gummerson, R.J., Hall, C. \& Hoff, W.D. (1980). Water Movement in Porous Building Materials - II: Hydraulic Suction and Sorptivity of Brick and Other Masonry Materials. Building and Environment, 15, 101-108.

[14] Cassar, M \& Hawkins, C (Eds) (2007). Engineering Historic Futures Stakeholders Dissemination and Scientific Research Report. University College London/Centre for Sustainable Heritage. https://discovery.ucl.ac.uk/id/eprint/2612/.

[15] Laycock, E.A. \& Hetherington, S. (2020). Laboratory assessment of the flood resilience of traditional masonry construction. Unpblished report AA8975, March 2020. Sheffield Hallam University/Natural \& Built Environment. 